J. Clin. Chem. Clin. Biochem.

Vol. 18, 1980, pp. 169-174

\title{
Determination of Methotrexate in Serum by a Rapid, Fully Mechanized Enzyme Immunoassay (EMIT) ${ }^{1}$ )
}

\author{
By M. Oellerich, P. Engelhardt, M. Schaadt and V. Diehl \\ Technical assistance: I. Isberner and H. H. Ripke
}

Institut für Klinische Chemie, Neurologische Klinik, Department Innere Medizin,
Medizinische Hochschule Hannover

(Received July 16/September 29, 1979)

Summary: A homogeneous enzyme immunoassay for the determination of methotrexate in serum (EMIT, Syva Corp.) was fully mechanized by the use of an Eppendorf analyzer 5010. Coefficients of variation from day to day were in the range $2-16 \%$. A comparison of the results obtained by EMIT and a radioimmunoassay (Methotrexate ${ }^{125}$ I Radioimmunoassay Kit, Diagnostic Biochemistry Inc.) in a series of 50 samples from patients showed a good correlation between both methods. The specificity of the EMIT assay appeared to be adequate. The time required for the determination of about 20 patient samples by this procedure was only about 80 minutes. From our clinical experience the EMIT assay appears to be well suited for routine monitoring of methotrexate serum concentrations above $0.1 \mu \mathrm{mol} / 1$ during intrathecal and high dose methotrexate therapy.

\section{Bestimmung von Methotrexat im Serum mit einem rasch durchführbaren, vollmechanisierten Enzymimmunotest (EMIT)}

Zusammenfassung: Ein homogener Enzymimmunotest zur Bestimmung von Methotrexat im Serum (EMIT, Syva Corp.) wurde mit Hilfe eines Eppendorf Enzymautomaten 5010 vollmechanisiert. Die Variationskoeffizienten von Tag zu Tag lagen bei etwa 2-16\%. Ein Vergleich der Ergebnisse, welche mit EMIT und einem Radioimmunotest (Methotrexate ${ }^{125}$ I Radioimmunoassay Kit, Diagnostic Biochemistry Inc.) bei einer Serie von 50 Patientenproben erhalten wurden, èrgab eine gute Korrelation beider Verfahren. Die Spezifität des EMIT-Tests erschien ausreichend. Für die Bestimmung von 20 Patientenproben wurden mit diesem Verfahren nur etwa 80 Minuten benötigt. Nach unseren klinischen Erfahrungen scheint der EMIT-Test bei der intrathekalen und hochdosierten Methotrexat-Therapie gut zur routinemäßigen Ưberwachung von Methotrexat-Konzentrationen im Serum über $0,1 \mu \mathrm{mol} / 1$ geeignet zu sein.

\section{Introduction}

Methotrexate ${ }^{2}$ ), an inhibitor of dihydrofolate reductase (EC 1.5.1.3), is widely used in the chemotherapy of various neoplastic diseases, such as breast cancer, acute leucaemia or osteogenic sarcoma, and in the treatment of non-neoplastic disorders such as severe psoriasis (1). With systemic and intrathecal regimens for methotrexate in current use, serious toxicities such as myelosuppression, gastrointestinal mucositis, renal failure and neuro-

\footnotetext{
1) Parts of this study have been reported at "Kongreß der Deutschen Gesellschaft für Laboratoriumsmedizin" in Berlin 1979.

2) 4-Amino-N ${ }^{10}$-methyl-pteroylglutamic acid (amethopterin).

Abbreviation: $\mathrm{EMIT}^{\circledR}=$ enzyme multiplied immunoassay technique.
}

toxicity have been observed (1). Especially patients who receive high-dose methotrexate regimens risk the development of life-threatening side reactions. Toxicity occurs if certain thresholds for the duration of methotrexate exposure and the serum concentration of this compound are exceeded. For bone marrow and gastrointestinal epithelium, for example, these thresholds appear to be $0.02 \mu \mathrm{mol} / 1$ and about 42 hours (1). The severity of toxicity depends more on the extent to which the timethreshold is exceeded than on the magnitude of the elevation of the methotrexate concentration above the concentration-threshold (1). According to the literature serum methotrexate levels $<5-10 \mu \mathrm{mol} / 1$ at 24 hours $(2,32),<0.5-1.0 \mu \mathrm{mol} / \mathrm{l}$ at 48 hours $(2-4)$ and $<0.05$ $\mu \mathrm{mol} / 1$ at 72 hours (2) after initiation of the methotrexate therapy point to an adequate serum methotrexate clearance and usually will not produce toxicity. 
Monitoring of serum methotrexate concentrations may be helpful in the identification of patients with elevated methotrexate levels. Life-threatening side reactions may then be averted by administration of the antidote citrovorum factor (5-formyltetrahydrofolate; trade name: leucovorin), and by taking measures to improve renal methotrexate excretion, such as intravenous hydration and alkalinization of the urine (1). Furthermore, the methotrexate serum levels can be monitored, so that the administration of citrovorum factor is continued until the methotrexate concentration has fallen below the toxicological relevant borderline at about $0.08-0.1$ $\mu \mathrm{mol} / \mathrm{l}(1)$, preferably below $0.01 \mu \mathrm{mol} / 1(3,5)$.

Monitoring of serum methotrexate levels has been recommended recently by various authors $(1-7)$. So far, for the determination of methotrexate, relatively complex microbiological $(7)$, fluorometric $(8,9)$, enzymatic $(10,11)$ and high-pressure liquid chromatographic $(12,13)$ methods have been used. A disadvantage of competitive protein binding assays $(14$, $15)$ and radioimmunoassays $(16,17)$ is that these methods require the use of radioactive material. Recently a homogeneous enzyme immunoassay for the determination of methotrexate (18) has become commercially available (EMIT Methotrexate Assay, Syva Corp., Palo Alto, U.S.A.). In the present study we report on an evaluation of a mechanized version of this EMIT assay and our preliminary clinical experience with this test.

\section{Material and Methods}

\section{Origin of specimens}

Serum samples $(n=168)$ containing methotrexate were obtained from patients with various neoplastic diseases such as breast cancer, acute lymphocytic leucaemia and osteogenic sarcoma.

\section{Materials}

The reagents for the enzyme immunoassay (EMIT), the determination of aspartate aminotransferase (EC 2.6.1.1; Merckotest No. 3375), alanine aminotransferase (EC 2.6.1.2; Merckotest No. 3376), hypoxanthine and adenine were obtained from E. Merck (D-6100 Darmstadt), the Methotrexate ${ }^{125}$ I Radioimmunoassay Kit from Diagnostic Biochemistry Inc. (San Diego, U.S.A.), methotrexate, calcium $\mathrm{N}^{5}$-formyltetrahydrofolate and thiotepa from Cyanamid (D-8190 Wolfratshausen), aminopterin, folic acid, dihydrofolic acid, tetrahydrofolic acid and barium $\mathrm{N}^{5}$-methyltetrahydrofolate from Sigma (D-8021 Taufkirchen), 6-mercaptopurine, allopurinol and azathioprine from Wellcome (D-3006 Burgwedel 1), trimethoprim from Ratiopharm (D-7902 Blaubeuren), daunorubicin, doxorubicin from Montedison Farmazeutica (D-7800 Freiburg), cyclophosphamide from Asta (D-4800 Bielefeld 14), 5-fluorouracil from Hoffmann-La-Roche (D-7889 Grenzach-Wyhlen), vincristine and vinblastine from Lilly (D-6380 Bad Homburg), colchicine from Kali-Chemie (D-3000 Hannover 1), cy tarabine from Mack (D-7918 Illertissen), 4-Amino-4-deoxy- $\mathrm{N}^{10}$-methylpteroic acid and 7-hydroxymethotrexate were obtained from Syva Corp., Palo Alto, U.S.A.

\section{Enzyme immunoassay (EMIT)}

The original procedure of the EMIT methotrexate assay was fully mechanized by adapting this test to the Eppendorf analyzer 5010 (Eppendorf, D-2000 Hamburg) in the same way as previously described for the EMIT assays of phenobarbital, phenytoin and theophylline $(19,20)$.

\section{Radioimmunoassay}

Methotrexate determinations by radioimmunoassay were carried out by use of the Methotrexate ${ }^{125}$ I Radioimmunoassay Kit according to the instructions of the manufacturer.

\section{Results and Discussion}

\section{Precision}

The coefficients of variation from day to day were $2-16 \%$ with EMIT (tab. 1) and with the radioimmunoassay about $10 \%$. (mean value with standard deviation: $1.02 \pm 0.11 \mu \mathrm{mol} / \mathrm{l}$, number of contributing values: 5 ). The precision data of EMIT and radioimmunoassay refer to mean values of duplicate determinations and single determinations respectively.

Tab. 1. The precision from day to day of the EMIT assay for determination of methotrexate in serum. Assays were performed in duplicate on 24 days and the mean values were used for calculation of the precision.

\begin{tabular}{|c|c|c|}
\hline $\begin{array}{l}\text { Methotrexate } \\
(\mu \mathrm{mol} / 1)\end{array}$ & $\begin{array}{l}\overline{\bar{x}} \\
(\mu \mathrm{mol} / \mathrm{l})\end{array}$ & $\begin{array}{l}\mathrm{CV}^{\mathrm{a})} \\
(\%)\end{array}$ \\
\hline \multicolumn{3}{|l|}{ Calibrators } \\
\hline $\begin{array}{l}0.2 \\
0.5 \\
1.0 \\
1.5 \\
2.0\end{array}$ & $\begin{array}{l}0.19 \\
0.51 \\
1.01 \\
1.50 \\
1.96\end{array}$ & $\begin{array}{r}15.7 \\
8.7 \\
4.1 \\
4.1 \\
2.4\end{array}$ \\
\hline \multicolumn{3}{|l|}{ Control sera $\left.{ }^{b}\right)$} \\
\hline $1000^{0.77}$ & $1002^{0.77}$ & $\begin{array}{l}5.1 \\
7.2\end{array}$ \\
\hline
\end{tabular}

a) Mean value $(\bar{x})$ with coefficient of variation

b) EMIT methotrexate control (Syva)

\section{Accuracy}

The recovery of methotrexate added to drug-free pooled human serum (concentration range $0.3-1.9 \mu \mathrm{mol} / 1$ ) with EMIT was $100-107 \%$, and with the radioimmunoassay was $105-120 \%$ (tab. 2).

Furthermore the results measured by EMIT and radioimmunoassay in 50 specimens from patients were compared. The correlation between the results was good $(r=0.974)$. The slope of the line and the intercept were calculated by use of the standardized principal component analysis $(21,22)$, which in contrast to the classical regression analysis represents a bivariate procedure. The slope of the line points to a proportional difference of about $10 \%$ (fig. 1). Accordingly the mean value of the results obtained by EMIT (y: $0.48 \pm 0.36 \mu \mathrm{mol} / 1)$ was significantly lower than that of the values determined by radioimmunoassay $(x: 0.53 \pm 0.40 \mu \mathrm{mol} / 1$; $t$-value 3.45 , $\mathrm{p}<0.0025)$. This discrepancy appears to be due to the elevated recovery of methotrexate by the radioimmunoassay (tab. 2). Reproducible deviations of more than $30 \%$ between the results of both assays occurred in 2 out of 50 cases. 
Tab. 2. The recovery of methotrexate by EMIT and radioimmunoassay in spiked serum samples. Determinations were performed by EMIT on five and by radioimmunoassay on three days.

\begin{tabular}{|c|c|c|c|c|c|c|}
\hline \multirow{2}{*}{$\begin{array}{l}\text { Metho- } \\
\text { trexate } \\
\text { weighed } \\
\text { in } \\
(\mu \mathrm{mol} / \mathrm{l})\end{array}$} & \multicolumn{3}{|l|}{ EMIT } & \multicolumn{3}{|c|}{ Radioimmunoassay } \\
\hline & $\begin{array}{l}\text { Found } \\
(\mu \mathrm{mol} / \mathrm{l})\end{array}$ & & $\begin{array}{l}\text { Recovery } \\
(\%)\end{array}$ & $\begin{array}{l}\text { Found } \\
(\mu \mathrm{mol} / \mathrm{l})\end{array}$ & & $\begin{array}{l}\text { Recovery } \\
\text { (\%) }\end{array}$ \\
\hline $\begin{array}{l}0.30 \\
0.80 \\
1.20 \\
1.90\end{array}$ & $\begin{array}{l}0.30 \\
0.83 \\
1.28 \\
1.90\end{array}$ & $\begin{array}{l}(10)^{a)} \\
(5) \\
(10) \\
(10)\end{array}$ & $\begin{array}{l}100 \\
104 \\
107 \\
100\end{array}$ & $\begin{array}{l}0.36 \\
0.89 \\
1.26 \\
2.05\end{array}$ & $\begin{array}{l}(4) \\
(5) \\
(5) \\
(5)\end{array}$ & $\begin{array}{l}120 \\
111 \\
105 \\
108\end{array}$ \\
\hline
\end{tabular}

a) Mean value and number of contributing values in parenthesis

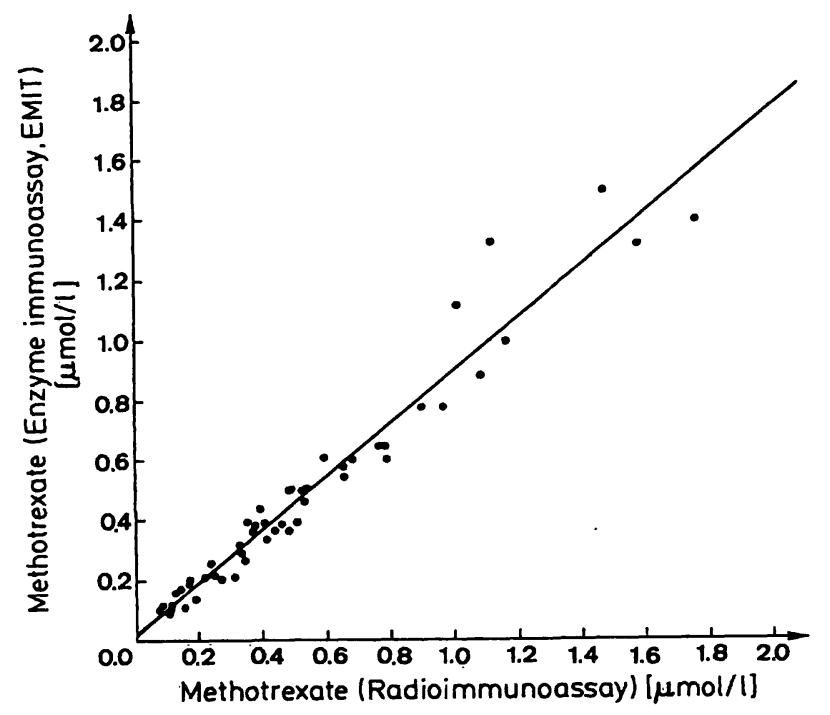

Fig. 1. Serum methotrexate concentrations as measured by EMIT and radioimmunoassay $(n=50)$. Slope: 0.897 . Intercept: $0.008 \mu \mathrm{mol} / 1$, correlation coefficient: 0.974 .

\section{Specificity}

The specificity of the EMIT assay was tested by the determination of the cross-reactivity of compounds structurally related to methotrexate and various other drugs. Aminopterin caused a relevant cross-reaction in this assay (tab. 3). This drug, however, is usually not administered together with methotrexate.

Folic acid, dihydrofolic acid, $\mathbf{N}^{5}$-formyltetrahydrofolate and $\mathrm{N}^{5}$-methyltetrahydrofolate showed a noticeable cross-reactivity only at concentrations, which were about 3-5 orders of magnitude above the normal range for serum levels of folic acid and its derivatives (16). After intramuscular or oral administration of $15 \mathrm{mg}$ citrovorum factor, serum concentrations of $\mathrm{N}^{5}$-formyltetrahydrofolate and its metabolite $\mathrm{N}^{5}$-methyltetrahydrofolate reached peak levels of less than $2 \mu \mathrm{mol} / 1$ (23). Accordingly no false poșitive results were obtained with patients $(n=3)$ receiving no methotrexate, when a standard dose of $15 \mathrm{mg}$ citrovorum factor was repeated. ly intravenously administered, or elevated serum concentrations of folate $(30-50 \mathrm{nmol} / \mathrm{l})$ were present.
Tab. 3. Cross-reactivity of various substances in serum ${ }^{a}$ ) with the EMIT methotrexate assay.

\begin{tabular}{|c|c|c|}
\hline Compound & (Trade name) & $\mu \mathrm{mol} / 1^{\mathrm{b})}$ \\
\hline $\begin{array}{l}\text { Aminopterin } \\
\text { 4-Amino-4-deoxy-N } 10 \\
\text { methylpteroic acid }\end{array}$ & & $\begin{array}{l}3.8 \cdot 10^{-1} \\
4.4 \cdot 10^{-1}\end{array}$ \\
\hline Folic acid & & $1.8 \cdot 10$ \\
\hline 7-Hydroxymethotrexate & & $9.2 \cdot 10$ \\
\hline Dihydrofolic acid & & $1.4 \cdot 10^{2}$ \\
\hline Tetrahydrofolic acid & & $1.7 \cdot 10^{2}$ \\
\hline $\begin{array}{l}\text { Calcium } N^{5} \text {-formyltetra- } \\
\text { hydrofolate }\end{array}$ & (Leucovorin) & $2.5 \cdot 10^{2}$ \\
\hline $\begin{array}{l}\text { Barium } N^{5} \text {-methyltetra- } \\
\text { hydrofolate }\end{array}$ & & $3.5 \cdot 10^{2}$ \\
\hline Azathioprine & (Imurek) & $1.0 \cdot 10^{3}$ \\
\hline Trimethoprim & (Trimethoprim comp.) & $4.0 \cdot 10^{3}$ \\
\hline Daunorubicin & (Daunoblastin) & $>1.0 \cdot 10^{3}$ \\
\hline Doxorubicin & (Adriblastin) & $>1.0 \cdot 10^{3}$ \\
\hline 6-Mercaptopurine & (Puri-Nethol) & $>5.0 \cdot 10^{3}$ \\
\hline Allopurinol & (Zyloric) & $>5.0 \cdot 10^{3}$ \\
\hline Cyclophosphamide & (Endoxan) & $>5.0 \cdot 10^{3}$ \\
\hline 5-Fluorouracil & (Fluorouracil „Roche“) & $>5.0 \cdot 10^{3}$ \\
\hline Vincristine & (Vincristin Lilly) & $>5.0 \cdot 10^{3}$ \\
\hline Vinblastine & (Velbe) & $>5.0 \cdot 10^{3}$ \\
\hline Colchicine & (Colchicum-Dispert) & $>5.0 \cdot 10^{3}$ \\
\hline Cytarabine & (Alexan) & $>5.0 \cdot 10^{3}$ \\
\hline $\begin{array}{l}\mathbf{N}, \mathbf{N}^{\prime}, \mathbf{N}^{\prime \prime}-\text { Triethylenethio- } \\
\text { phosphoramide }\end{array}$ & (Thiotepa „Lederle“) & $>5.0 \cdot 10^{3}$ \\
\hline Hypoxanthine & & $>5.0 \cdot 10^{3}$ \\
\hline Adenine & & $5.0 \cdot 10^{3}$ \\
\hline
\end{tabular}

a) Substances were added to drug-free pooled human serum

b) Concentration producing a deviation of $30 \%$ from the expected value in a sample containing $1.0 \mu \mathrm{mol} / 1$ methotrexate.

In accordance with the manufacturer (24) we observed that the metabolites of methotrexate, 4-amino-4-deoxy$\mathrm{N}^{\mathbf{1 0}}$-methylpteroic acid and 7-hydroxymethotrexate, which show only a relatively weak cytostatic effect (5), interfere distinctly at concentrations above $0.4 \mu \mathrm{mol} / \mathrm{l}$ and $90 \mu \mathrm{mol} / 1$ respectively (tab. 3). As 7-hydroxyme thotrexate levels were reportedly below $90 \mu \mathrm{mol} / 1$ during high-dose methotrexate-therapy (13), a relevant interference of this metabolite usually appears to be improbable. It is not known whether serum 4-amino-4-deoxy$\mathrm{N}^{10}$-methylpteroic acid (25) occurs in sufficiently high concentration to cause an interference.

With the remaining substances tested (tab. 3) no relevant cross-reactivity was observed.

\section{Interferences}

In spiked serum samples bilirubin (up to $600 \mu \mathrm{mol} / \mathrm{l}$ ), haemoglobin (up to $10 \mathrm{~g} / \mathrm{l}$ ) and triglycerides (up to $12 \mathrm{mmol} / \mathrm{l}$ ) caused deviations of less than $10 \%$ from the expected methotrexate values in the EMIT assay.

\section{Detectability}

The detection limit of methotrexate by EMIT was approximately at $0.1 \mu \mathrm{mol} / \mathrm{l}$. At this methotrexate concentration a coefficient of variation of about $30 \%$ (mean 
value: $0.11, \mathrm{n}=10$ ) was found within series. Though the detection limit of the EMIT assay is about 3 orders of magnitude above that of the radioimmunoassay, the EMIT assay usually appears to be sensitive enough for routine monitoring of methotrexate concentrations during the first decisive $48-72$ hours after high dose administration of methotrexate, or the time until the level of this drug has fallen below $0.1 \mu \mathrm{mol} / 1$. As methotrexate, however, inhibits DNA synthesis in bone marrow and intestinal epithelium at concentrations above 0.01 $\mu \mathrm{mol} / \mathrm{l}(26)$, it appears necessary to monitor me thotrexate concentrations down to this level in patients showing manifest (3) or questionable toxicity. Therefore the detectability of the EMIT assay has to be adequately improved.

\section{Practicability and costs}

Compared with the radioimmunoassay, the EMIT test showed better practicability. A disadvantage of the radioimmunoassay is that one or more dilutions have to be prepared from every sample, as the calibration curve ranges from $0.2-4.4 \mathrm{nmol} / \mathrm{l}$. The time required for the determination of about 20 patients samples containing methotrexate concentrations within the clinically relevant range of $0.1-2.0 \mu \mathrm{mol} / 1$ is about 80 minutes by our fully mechanized modification of the EMIT assay, and approximately 270 minutes by radioimmunoassay. A single methotrexate determination for emergency situations can be performed by EMIT within 40 and by radioimmunoassay in about 80 minutes.

As already frequently pointed out $(30,31)$, the EMIT technique has the advantage that contact with radioactive material is avoided, the reagents have a long shelflife and its mechanization is easy. Compared with the original procedure our fully mechanized version of the EMIT assay shows better practicability, a higher sample throughput per hour and a reduction of costs for reagents and technician time by about $20-40 \%$ (based on a series of 10-30 patients samples). The costs for a methotrexate determination including standards, control sera, reagents, pertinent supplies and technician time are about $14 \mathrm{DM}$ per EMIT test and about $13 \mathrm{DM}$ with the radioimmunoassay, for a series of 20 samples. A single methotrexate determination is much more expensive (tab. 4).

\section{Clinical experience}

Methotrexate serum concentrations were determined by EMIT in samples from patients $(n=5)$ who repeatedly received an intrathecal injection of $25 \mathrm{mg}$ methotrexate $\left(=12-16 \mathrm{mg} / \mathrm{m}^{2}\right)$ once a week because of diffuse, leptomeningeal infiltrations due to acute lymphocytic leucaemia, malignant lymphoma or breast carcinoma. With all of these patients only relatively low serum methotrexate concentrations were observed (tab. 5), and
Tab. 4. Comparison of the costs of a quantitative determination of methotrexate by EMIT adapted to the Eppendorf analyzer $\mathbf{5 0 1 0}$ and radioimmunoassay.

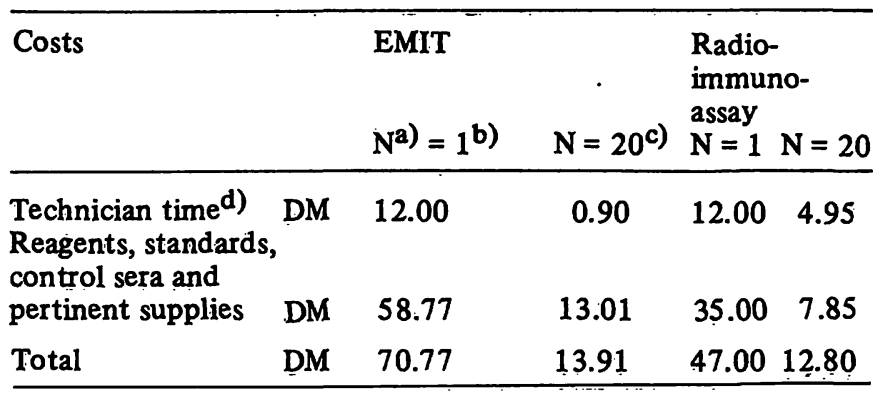

a)' $\mathrm{N}=$ number of specimens per series

b) zero calibrator and sample analyzed in duplicate, single measurements of all other calibrators

c) all samples and calibrators analyzed in duplicate

d) costs per minute technician time 0.60 DM (27)

Tab. 5. Serum concentrations in patients $(n=5)$ repeatedly treated with an intrathecal methotrexate dosage of $25 \mathrm{mg} /$ week $\left(12-16 \mathrm{mg} / \mathrm{m}^{2}\right.$. week).

\begin{tabular}{lrrr}
\hline $\begin{array}{l}\text { Time after intrathecal } \\
\text { methotrexate injection }\end{array}$ & $\begin{array}{l}\text { Methotrexate concentration } \\
\text { in serum } \\
\text { median }^{\mathrm{a}} \\
(\mu \mathrm{mol} / \mathrm{l})\end{array}$ & $\begin{array}{l}\text { range } \\
(\mu \mathrm{mol} / \mathrm{l})\end{array}$ & $\mathrm{n}^{\mathrm{b}}$ \\
\hline 1 & 0.35 & $<0.10-0.78$ & 21 \\
3 & 0.43 & $<0.10-1.09$ & 22 \\
6 & 0.42 & $0.21-0.67$ & 23 \\
24 & 0.10 & $<0.10-0.17$ & 22 \\
48 & $<0.10$ & - & 18 \\
\hline
\end{tabular}

a) median and range are given as the contributing values did not show a normal distribution

b) number of contributing values

48 hours after intrathecal administration of this compound methotrexate serum levels were always below $0.1 \mu \mathrm{mol} / 1$. Accordingly no relevant adverse reactions occurred with these patients. The serum methotrexate concentrations observed (tab. 5) after intrathecal injection of this substance are of the same order of magnitude as those described in the literature (28).

The EMIT assay also appears to be well suited for monitoring of serum methotrexate levels during high-dose methotrexate therapy. In figure 2 the time course of the serum methotrexate concentrations in a 20 year old female patient with osteogenic sarcoma during and after the infusion of $250 \mathrm{mg} / \mathrm{kg}$ methotrexate is illustrated. Citrovorum factor $(15 \mathrm{mg})$ was given as indicated every six hours. Intravenous hydration (glucose $50 \mathrm{~g} / 1$ (Travenol) $1500 \mathrm{ml} / 24$ hours; ringer-lactate solution (Braun Melsungen) $1500 \mathrm{ml} / 24$ hours) and alkalinization $\left(\mathrm{NaHCO}_{3}\right.$-solution $60 \mathrm{mmol} / 24$ hours) was started 12 hours before the beginning of the methotrexate infusion and then maintained for a further 72 hours. The 


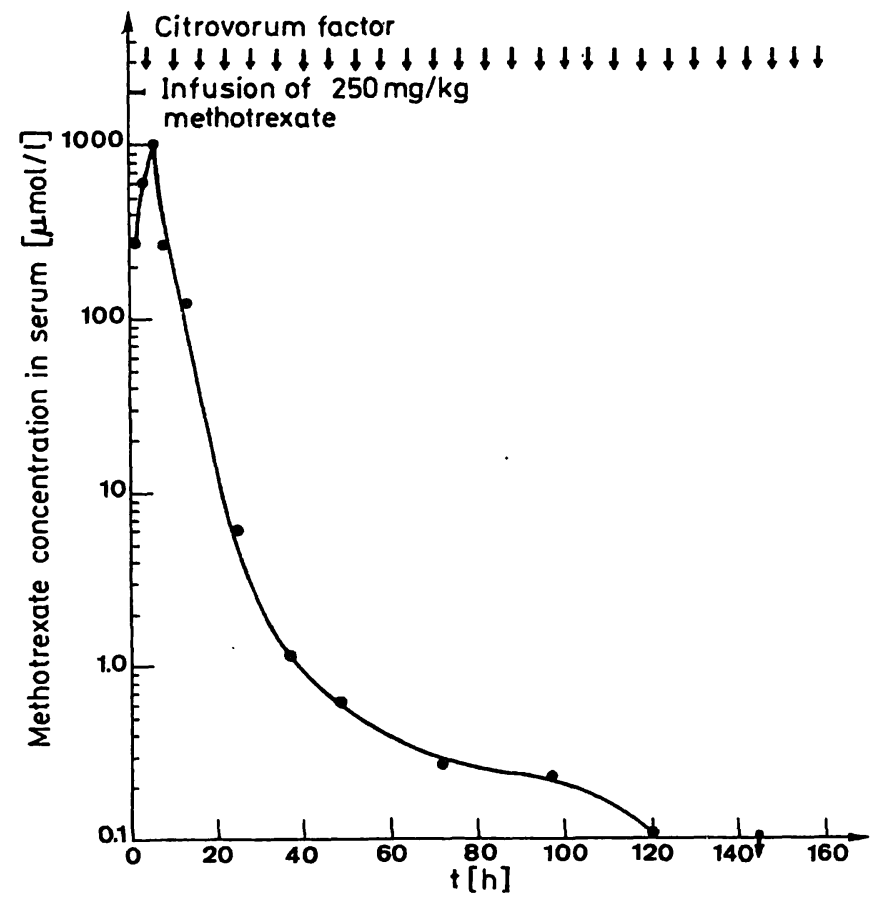

Fig. 2. Serum methotrexate concentrations in a 20 year old female patient with osteogenic sarcoma during and after a four hour period of infusion of $250 \mathrm{mg} / \mathrm{kg}$ methotrexate. Citrovorum factor $(15 \mathrm{mg})$ was given as indicated by arrows every six hours.

creatinine clearance of the patient $(132 \mathrm{ml} / \mathrm{min})$ was in the normal range. The serum methotrexate levels at 24 and 48 hours after the beginning of the methotrexate infusion were below the corresponding toxicologically relevant borderlines of $10 \mu \mathrm{mol} / 1$ and 1.0 $\mu \mathrm{mol} / 1$ respectively. Accordingly no relevant adverse reactions were observed. At 72 and 96 hours, however, the serum methotrexate levels were distinctly above $0.1 \mu \mathrm{mol} / 1$ and a transient rise of alanine aminotransferase (up to $108 \mathrm{U} / \mathrm{l}$ ) and of aspartate aminotransferase (up to $63 \mathrm{U} / 1$ ) occurred. A myelosuppression was not encountered. The methotrexate levels determined by EMIT at 24 and 48 hours were in accordance with those observed by other authors at the same dosage of this drug (1-4). The slightly elevated methotrexate concen- trations at 72 and 96 hours might be due to a release of methotrexate from storage sites. Wang et al. observed in some patients even higher methotrexate plasma concentrations at 72 hours than at 48 hours, presumably due to such a phenomenon (29).

During the terminal serum disappearance phase of methotrexate, following its high-dose administration, an increased concentration of methotrexate metabolites in the serum is to be expected (1). This may be important in the genesis of toxic adverse reactions (1) and might cause an interference in enzyme- and radioimmunoassays for the determination of methotrexate $(24,25)$. Therefore it appears necessary to investigate the serum concentrations of 4-amino-4-deoxy- $\mathrm{N}^{10}$-methylpteroic acid and 7-hydroxymethotrexate, the major metabolites of methotrexate, during this period. As high-pressure liquid chromatography has already been successfully applied to the determination of 7-hydroxymethotrexate (13), it is planned to use this technique in further studies on serum concentrations of methotrexate metabolites.

\section{Conclusion}

Compared with other procedures used so far for methotrexate determination, the EMIT assay has the advantage that it can be more easily mechanized and rapidly performed. The detectability of the EMIT assay needs to be improved somewhat, in order to detect methotrexate concentrations above $0.01 \mu \mathrm{mol} / \mathrm{l}$; relevant studies are in progress. Except for this limitation the EMIT assay proved to be dependable and appeared to be well suited for routine monitoring of serum methotrexate concentrations during intrathecal and high-dose methotrexate therapy.

\section{Acknowledgement}

We thank Dr. H. Haindl (Hannover) for the determination of serum folate concentrations.

\section{References}

1. Bleyer, W. A. (1978), Cancer 41, 36-51.

2. Isacoff, W. H., Eilber; F., Tabbarah, H., Klein, P., Dollinger, M., Lemkin, S., Sheehy, P., Cone, L., Rosenbloom, B., Sieger, L. \& Block, J. B. (1978), Cancer Treat. Rep. 62, $1295-1304$

3. Stoller, R. G., Hande, K. R., Jaçobs, S. A., Rosenberg, S. A. \& Chabner, B. A. (1977), New Eng. J. Med. 297, 630-634.

4. Nirenberg, A., Mosende, C., Mehta, B. M., Gisolfi, A. L. \& Rosen, G. (1977), Cancer Treat. Rep. 61, 779-783.

5. Shen, D. D. \& Azarnoff, D. L. (1978), Clin. Pharmacokinet. 3, 1-13.

6. Salasoo, S., Irving, M. G., Lam-Po-Tang, R., O'GormanHughes, D. \& Freedman, A. (1976), Med. J. Australia 1, 777-779.
7. Noble, W. G., White, P. M. \& Baker, M. (1975), J. Invest. Dermatol. 64, 69-76.

8. Freeman, M. V. (1957), J. Pharmacol. Exp. Ther. 120, $1-8$.

9. Kinkade, J. M., Vogler, W. R. \& Dayton, P. G. (1974), Biochem. Med. 10, 337-350.

10. Falk, L. C., Clark, D. R., Kalman, S. M. \& Long, T. F. (1976), Clin. Chem. 22, 785-788.

11. Persijn, J. P. (1979), J. Clin. Chem. Clin. Biochem. 17, 235-239.

12. Nelson, J. A., Harris, B. A., Decker, W. J. \& Farquhar, D. (1977), Cancer Res. 37, 3970-3973.

13. Watson, E., Cohen, J. L. \& Chan, K. K. (1978), Cancer Treat. Rep. 62, 381-387. 
14. Kamen, B. A., Takach, P. L., Vatev, R. \& Caston, J. D. (1976), Anal. Biochem. 70, 54-63.

15. Myers, C. E., Lippmann, M. E., Eliot, H. M. \& Chabner, B. A. (1975), Nat. Acad. Sci. 72, 3683-3686.

16. Paxton, J. W. \& Rowell, F. J. (1977), Clin. Chim. Acta 80, 563-572.

17. Aherne, W., Piall, E. \& Marks, V. (1978), Ann. Clin. Biochem. $15,331-334$

18. Gushaw, J. B. \& Miller, J. G. (1978), Clin. Chem. 24, 1032.

19. Oellerich, M., Külpmann, W. R., Haeckel, R. \& Heyer, R. (1977), J. Clin. Chem., Clin. Biochem. 15, 353-358.

20. Oellerich, M., Sybrecht, G. W. \& Haeckel, R. (1979), J. Clin. Chem. Clin. Biochem. 17, 299-302.

21. Feldmann, U., Schneider, B. \& Haeckel, R., J. Clin. Chem. Clin. Biochem. In prep.

22. Anderson, T. W. (1958), An introduction of multivariate statistical analysis, Wiley, New York.

23. Mehta, B. M., Gisolfi, A. L., Hutchinson, D. J., Nirenberg, A., Kellick, M. G. \& Rosen, G. (1978), Cancer Treat. Rep. 62, 345-350.

24. De Porceri-Morton, C., Chang, J., Specker, M. \& Bastiani, R. (1978), Performance evaluation of the EMIT Methotrexate Assay, Syva, Palo Alto, Calif.
25. Paxton, J. W. (1979), Clin. Chem. 25, 491-492.

26. Chabner, B. A. \& Young, R. C. (1973), J. Clin. Invest. 52, 1804-1811.

27. Haeckel, R. (1979), Rationalisierung des medizinischen Laboratoriums, 2nd ed., GIT-Verlag Darmstadt.

28. Bleyer, W. A. \& Dedrick, R. L. (1977), Cancer Treat. Rep. $61,703-708$.

29. Wang, Y., Lantin, E. \& Sutow, W. W. (1976), Clin. Chem. $22,1053-1056$.

30. Haeckel,.R. Oellerich, M. (1979), Lab. Med. 1, 121-131.

31. Oellerich, M. (1980), J. Clin. Chem. Clin. Biochem. 18, 197-208.

32. Evans, W. E., Pratt, C. B., Taỳlor, R. H., Barker, L. F. \& Crom, W. R. (1979), Cancer Chemother. Pharmacol. 3, $161-166$.

\section{Note added to the proof}

After completion of the experiments a new lot of this EMIT assay was obtained, in which the linearity range was reduced to $1.5 \mu \mathrm{mol} / 1$.
Priv.-Doz. Dr. M. Oellerich Institut für Klinische Chemie Medizinische Hochschule Hannover D-3000 Hannover 61 